http://dx.doi.org/10.12775/szhf.2019.010

\author{
JOANNA USAKIEWICZ \\ Uniwersytet w BiaŁymstoku, Polska \\ ORCID: 0000-0003-2767-4024 \\ E-MAIL: JOANNA.USAKIEWICZ@ONET.EU
}

\title{
Anna Maria van Schurman (1607-1678) - Ocellus Niderlandów
}

Anna Maria van Schurman to siedemnastowieczna uczona, poetka, malarka, która już za życia zyskała wielką sławę w Europie. Nazywana była przez współczesnych Pallas z Utrechtu (Pallas Ultraiectina), Dziesiątą Muzą (Decima Musarum), Minerwą swoich czasów (sui seculi Minerva)ํ. Polski szlachcic, Hieronim Gratus Moskorzowski (vel Moskorzewski; ok. 1627-ok. 1661), opisując w swoim Diarius rerum notabilium zasłyszane okoliczności spotkania 26 grudnia 1645 roku polskiej królowej Ludwiki Marii z Anną Marią van Schurman, określił ją mianem ocellus („perełką/klejnoci$\mathrm{kiem} /$ rzeczą najcenniejszą") ${ }^{2}$. Pozostawiła po sobie utwory poetyckie, pisma

\footnotetext{
* Praca naukowa finansowana ze środków Ministra Nauki i Szkolnictwa Wyższego w ramach dotacji na utrzymanie potencjału badawczego przyznanej Uniwersytetowi w Białymstoku.

${ }^{1}$ Zob. np.: Anna Maria van Schurman, Opuscula Hebraea, Graeca, Latina, Gallica. Prosaica et metrica (Lejda: Ex Officina Elseviriorum, 1648), 338, 353 oraz G. D. J. Schotel, Anna Maria van Schurman ('s-Hertogenboch: Gebroeders Muller, 1853), 18, 22, 33 (Aanteekeningen en bijlagen).

${ }^{2}$ Zob. Karolina Targosz, Jana Sobieskiego nauki i peregrynacje (Wrocław-Warszawa-Kraków-Gdańsk-Łódź: Zakład Narodowy Imienia Ossolińskich Wydawnictwo Polskiej
} 
prozą, obrazy i ryciny. Najbardziej znany jej tekst to poświęcona problemowi edukacji kobiet Dissertatio de ingenii muliebris ad doctrinam et meliores litteras aptitudine (Lejda 1641). Napisała również: De vitae termino (Lejda 1639)

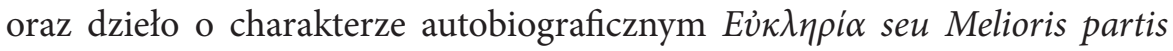
electio (Altona 1673), w którym nie tylko opisała koleje swego życia, ale także przedstawiła obronę swego przystąpienia do labadystów. Wydała również Opuscula Hebraea, Graeca, Latina, Gallica. Prosaica et metrica (Lejda 1648, później wznawiane). Anna Maria van Schurman prowadziła także rozległą korespondencję. Adresatami jej listów byli m.in.: André Rivet (1572-1651) francuski teolog, profesor Uniwersytetu w Lejdzie, Constantijn Huygens (1596-1687) - holenderski uczony, poeta i dyplomata, Marin Mersenne (1588-1648) - francuski duchowny katolicki i teolog, Pierre Gassendi (1592-1655) - francuski filozof, astronom i matematyk, Jean-Louis Guez de Balzac (1597-1654) - francuski pisarz i mecenas sztuki. W niniejszym tekście przedstawiony zostanie zarys sylwetki Anny Marii van Schurman. Kreśląc go, postaramy się uwypuklić nietuzinkowość tej uczonej kobiety, niezależność jej poglądów, ale przede wszystkim jej związki z filozofią, odnosząc się do jej wykształcenia i pism, a także osób, które znała ${ }^{3}$.

\section{Dzieciństwo i młodość: edukacja domowa i studia}

Anna Maria van Schurman urodziła się 5 listopada 1607 roku w Kolonii w Niemczech ${ }^{4}$. Jej ojciec - Frederik van Schurman - pochodził z rodziny ni-

Akademii Nauk, 1985), 144. Opis wydarzenia autorstwa Jeana le Laboureura zob. van Schurman Opuscula, 338 i n.

${ }^{3}$ Nie będziemy szczegółowo zajmować się twórczością artystyczną Anny Marii van Schurman. Zauważmy tylko, że jej talenty doceniali współcześni (w 1643 roku została przyjęta do Gildii Łukasza, do której należeli malarze, rzeźbiarze i grawerzy), a i dzisiaj jej prace obecne są w zbiorach muzealnych i bibliotecznych.

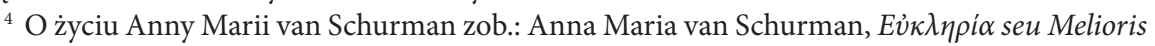
partis electio, Editio altera (Dessaviae: Sumptibus Societatis Typographicae, 1782); Schotel, Anna Maria van Schurman; Brigitte Hermann, La demoiselle savante ou Histoire d'Anne Marie de Schurman, 1607-1678 (Paris: Bartillat, 2003); Pieta van Beek, The First Female University Student: Anna Maria van Schurman (1636) (Utrecht: Igitur, Utrecht Publishing and Archiving 
derlandzkiej z Antwerpii, matka zaś - Eva von Harff - należała do niemieckiej szlachty. Przodkowie Anny Marii van Schurman uciekli do Niemiec przed prześladowaniami religijnymi lub działaniami wojennymi $\mathrm{w}$ rodzinnych stronach i utracili swoje dobra. Miała trzech braci: dwóch starszych, Hendrika Frederika (ok. 1603-ok. 1632) ${ }^{5}$ i Johana Godschalka (ok. 1605-1664) oraz młodszego Willema (ok. 1610-1615). Rodzina była wyznania kalwińskiego. Po kilku latach od narodzenia Anny Marii rodzina przeniosła się ostatecznie do Utrechtu, choć przez jakiś czas mieszkali też w niemieckim zamku rodowym von Harffów w Dreiborn (dokąd wyprowadzili się, gdy Kolonia zaczęła stawać się miastem coraz mniej tolerancyjnym religijnie), w okolicach Hagi (ponieważ ojciec chciał być blisko dworu) i w niderlandzkim Franeker (ze względu na studia medyczne jednego ze starszych braci Anny Marii). Ona sama większość swojego życia spędziła właśnie w Utrechcie.

Od wczesnego dzieciństwa zgodnie ze zwyczajem ówczesnych elit była nauczana $\mathrm{w}$ domu, a jej pierwszym nauczycielem, podobnie jak braci, był

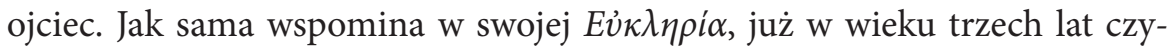
tała po niemiecku i recytowała z pamięci fragmenty Katechizmu heidelberskiego $(1563)^{6}$. Już w dzieciństwie rozbudzona została w niej bardzo silna religijność. Gdy miała siedem lat, oddano ją do francuskiej szkoły, aby miała kontakt $\mathrm{z}$ innymi dziećmi. Przebywała tam jednakże tylko dwa miesiące, rodzice uznali bowiem, że to otoczenie ma na nią zły wpływ. Następnie uczył ją w domu prywatny nauczyciel, nacisk położono na arytmetykę i muzykę, a także śpiew. Wtedy też zaczęła poznawać język łaciński. Gdy w wieku 11 lat zaczęła poprawiać łacińskie i francuskie wypowiedzi swoich starszych braci, ojciec pozwolił, aby uczyła się wspólnie z nimi. W tym okresie zaczęła uczyć się również języka greckiego. Z klasyki wybierano jej jednak odpowiednie lektury, a za takie uznano dzieła Homera i Wergiliusza. Rodzice bowiem w wychowaniu przedkładali troskę o chrześcijańską cnotę swych dzieci nad klasyczne wykształcenie. Jako jedenastolatka czytała więc żywoty męczenników. Szczególnie istotna najprawdopodobniej była lektura pracy Johna

Services, 2004); Anne R. Larsen, Anna Maria van Schurman, "The Star of Utrecht". The Educational Vision and Reception of a Savante (Oxon-New York: Routledge, 2016).

${ }^{5}$ Oprócz dat życia, o tym bracie Anny Marii van Schrman wiadomo tylko, że został pochowany w rodzinnej krypcie kościoła w Rhenen, gdzie spoczęła później także ich matka.

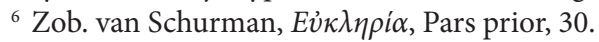


Foxe'a Commentarii Rerum in Ecclesia Gestarum (1554), młoda Anna Maria zafascynowała się bowiem wówczas symbolem protestanckiego heroizmu i męczeństwa - angielską królową Jane Grey (1536/37-1554), panującą przez dziewięć dni w roku 1553, ściętą po wstąpieniu na tron przez Marię I Tudor. Lekturą obowiązkową była również Biblia.

Mając 11 lat, rozpoczęła też studiowanie pism filozoficznych, a pierwszym myślicielem, z którym się zetknęła, był Seneka - ulubiony filozof jej ojca ${ }^{7}$. Stał się on także niezwykle istotnym myślicielem dla Anny Marii van Schurman. Uczyła się na jego tekstach zarówno języka łacińskiego, jak i filozofii, a poznając jego poglądy, dostrzegła, że spośród filozofów antycznych jego myśl jest najbliższa chrześcijaństwu. Wiele lat później, w 1658 roku, Anna Maria van Schurman napisała utwór pochwalny dla tłumaczki dzieł Seneki na język duński - Brigitte Thrott (1610-1662). Został on zamieszczony na początku wydania tego przekładu zatytułowanego Philosophus. Następnie poznawała m.in. pisma Cicerona oraz ojców Kościoła, w szczególności św. Augustyna.

Około roku 1620 Anna Maria van Schurman zaczęła być znana lokalnie ze swych talentów artystycznych i wykształcenia. W 1622 roku zainicjowała swoją rozległą korespondencję z uczonymi i twórcami swoich czasów. Pierwsze listy skierowała do Daniela Heinsiusa (1580-1655) - profesora w Lejdzie, filologa klasycznego i orientalisty, oraz do poety Jacoba Catsa (1577-1660), któremu przesłała swój wiersz, zawierający porównanie adresata z Ciceronem $^{8}$. Z roku 1623 (23 sierpnia) znana jest pierwsza jej próba kaligraficzna - nota gratulacyjna po łacinie dla mistrza szermierki z Antwerpii Gerarda Thibault (ok. 1574-1627). W tym samym roku dzięki bratu, Johanowi Godschalkowi, poznała André Riveta, będzie z nim korespondować i dyskutować. 15 listopada 1623 roku umarł jej ojciec, któremu przed śmiercią Anna Maria obiecała, że nigdy nie wyjdzie za mąż, lecz będzie kontynuowała swoje studia. Podjęła więc powołanie do bycia uczoną. Nadal studiowała pisma autorów klasycznych. Zaczęła szczególnie cenić sobie dzieła historyczne. Kilka lat po śmierci męża, w 1629 roku, matka Anny Marii kupiła dom zwany Achter de Dom w Utrechcie, położony blisko Uniwersytetu oraz mieszkania teologa Gijsberta Voeta (Gisbert Voetius; 1589-1676), do której to postaci

\footnotetext{
7 Zob. tamże, 32.

${ }^{8}$ Zob. van Schurman, Opuscula, 168-189; 256-257.
} 
jeszcze wrócimy. Rozbudzona w dzieciństwie religijność Anny Marii zaczęła przeradzać się w pragnienie męczeństwa dla Chrystusa - jako życiowe motto przyjęła myśl zaczerpniętą ze św. Ignacego z Antiochii (ok. 35-ok. 107): Amor meus crucifixus est.

Pod koniec lat dwudziestych XVII wieku Anna Maria van Schurman stała się sławna w Niderlandach. Brat opisał jej nadzwyczajne talenty w listach, np. do niderlandzkiego poety Caspara van Baerlego (Barlaeus, 1584-1648) w roku 1629. Sama Anna Maria van Schurman w 1633 roku wysyła do Constantijna Huygensa swój autoportret z łacińską inskrypcją.

Od października 1634 roku mentorem i bardzo istotną postacią w życiu Anny Marii van Schurman stał się Gisbert Voetius, kalwiński teolog, przeciwnik filozofii René Descartes’a, profesor teologii, hebrajskiego i języków orientalnych w Szkole w Utrechcie, która w 1636 roku została przekształcona w uniwersytet. Voetius najpierw kontynuował zapoczątkowane przez jej ojca nauczanie Anny Marii van Schurman greki, w szczególności koine i greki ojców Kościoła. Wśród lektur filozoficznych znalazły się dzieła Platona i Arystotelesa. Czytała również Homera, Pindara oraz greckich historyków. Jako jedna z nielicznych kobiet władających łaciną Cycerońską została zaproszona przez Voetiusa do napisania i wygłoszenia łacińskiej ody pochwalnej na inauguracji Uniwersytetu w Utrechcie 16 marca 1636 roku$^{9}$. Ułożyła trzydziestowierszową odę, w której nie tylko chwaliła nową uczelnię, ale wykorzystała też tę możliwość, aby upomnieć się o dostęp kobiet do instytucjonalnego kształcenia. Zwracając się do Minerwy, Anna Maria van Schurman pisała:

Ast quae (forte rogas) agitant tua pectora curae?

Non haec Virgineis pervia Sacra choris ${ }^{10}$.

\footnotetext{
${ }^{9}$ Ostatecznie do wygłoszenia nie doszło, gdyż wcześniej głośny tłum mieszkańców miasta chcących wziąć udział w uroczystości wtargnął do katedry, gdzie odbywało się wydarzenie, i zakłócił jego przebieg; zob. van Beek, The First Femal University Student, 51. Tekst łaciński w: Academiae Ultraiectinae Inauguratio una cum Orationibus inauguralibus (Utrecht: Ex Officina Aegidii et Petri Roman, 1636), strony nienumerowane. Oprócz wiersza łacińskiego Anna Maria van Schurman napisała też utwory po niderlandzku i po francusku.

${ }^{10}$ „Ale (zapytasz może) jakie troski poruszają twoje serce? / Nie ma świętego wstępu dla grona dziewcząt”. (Przekłady na język polski, o ile inaczej nie podano, Joanna Usakiewicz).
} 
I dalej, biorąc pod uwagę wszystkich ludzi - mężczyzn i kobiety - argumentowała:

Omnibus hic seritur, metiturque, ut amica quieti

Alma Themis, discors arceat Orbe Chaos;

Utque pio irradiet divina Scientia Cultu,

Et caleat summo quaelibet Ara Deo ${ }^{11}$.

Dzięki Voetiusowi, oddzielona i niewidoczna dla studentów płci męskiej, w jakimś rodzaju budki z kotarą czy za przepierzeniem, mogła uczestniczyć w wykładach, czyli była pierwszą kobietą studiującą na holenderskim uniwersytecie $^{12}$. Johan van Beverwijck (1594-1647), lekarz z Dordrechtu, przedstawia to w sposób następujący: „Lastinea Mantinea ende Axiothea Phliasia zijn van Plato geleert geweest ende quamen om hem onverhindert te hooren, in mans kleederen in sijn lessen. Beter is ' $t$ datter een bijsondere plaets voor de joffrouwen gemaeckt wert, daer sy alleen ende sonder gesien te worden, sitten: gelijck t' Utrecht voor de meer-wel-gemelte Joffrouw Anna Maria van Schurman"13. Do tego faktu nawiązuje też w swoim liście do Regiusa (Henri Le Roy; 1598-1679) z 24 maja 1640 roku René Descartes: „Także gdy tezy te będą dyskutowane, wybiorę się do Utrechtu, jeśli sobie tego życzysz; byle tylko nikt o tym nie wiedział i bylem mógł ukryć się w owej warowni, w której Panna van Schurman ma zwyczaj słuchać wykładów"14. Głównym przedmiotem studiów Anny Marii van Schurman była teologia - koningin van alle wetenschap („królowa wszystkich nauk”). Przebieg studiów teologicznych na Uniwersytecie w Utrechcie w tym okresie opisał Voetius w Exercitia et biblio-

${ }^{11}$ „Dla wszystkich tu się sieje i zbiera plony, oby przyjaciółka spokoju / łaskawa Temida oddaliła wrogi Chaos od Ziemi; / i oby dzięki pobożnemu kształceniu promieniała Boska wiedza, / / i każdy ołtarz płonął dla Najwyższego Boga”.

${ }^{12}$ Nie ma jednak dokumentu uniwersyteckiego to potwierdzającego, zob. van Beek, The First Female University Student, 57.

${ }_{13}$ „Lastinea z Mantinei oraz Aksjotea z Fliuntu były uczone przez Platona i aby go słuchać bez ukrywania się, przychodziły na jego lekcje w męskich ubraniach. Lepiej jest utworzyć specjalne miejsce dla pań, gdzie tylko one mogą siedzieć i nie są widziane, jak to miało miejsce w Utrechcie dla wspomnianej panny Anny Marii van Schurman"; Johan van Beverwijck, Van de Wtnementheyt des Vorovwelicken Geslachts (Dordrecht: Hendrick van Esch, 1643), 27-28.

${ }^{14}$ René Descartes, Listy do Regiusa. Uwagi o pewnym pisemku, przeł. Jerzy Kopania (Warszawa: Wydawnictwo Naukowe PWN, 1996), 9. 
theca studiosi Theologiae ${ }^{15}$. Nauka teologii trwała siedem lat. Pierwsze trzy lata miały charakter przygotowawczy: był to roczny cursus artium et philologiae oraz dwuletni cursus scientiarum seu philosophiae (lub inaczej: cursus philosophicus). Kolejne cztery lata poświęcano na właściwy cursus theologiae. Nauka odbywała się w oparciu o autorytet Biblii, pisma teologów oraz filozofów, takich jak Platon, a przede wszystkim Arystoteles. Zauważmy tu na marginesie, że sam Voetius nie podzielał do końca poglądów Arystotelesa, choć uznawał jego pisma za źródło mądrości. Uważał np. że kobiety powinny się kształcić, ponieważ zostały obdarzone przez Boga odpowiednimi predyspozycjami intelektualnymi i fizycznymi. Nie znaczy to, że popierał całkowitą równość kobiet i mężczyzn w dostępie do wiedzy i korzystania z jej owoców: według niego kobiety nie powinny sprawować funkcji politycznych i kościelnych ${ }^{16}$. Teologia zarówno dla Voetiusa, jak i dla Anny Marii van Schurman była nie tylko wiedzą teoretyczną, ale także sposobem życia codziennego. Należało do niej więc także praktykowanie modlitwy, przestrzeganie dni świątecznych oraz spełnianie uczynków miłosierdzia, a na tym polu już nietrudno zatrzeć różnice między kobietami i mężczyznami.

W czasie studiów Anna Maria van Schurman rozwijała również swoją wiedzę w zakresie filozofii i uczyła się kolejnych języków, przede wszystkim orientalnych (m.in. syryjskiego, aramejskiego, perskiego). Zajęcia na uniwersytecie zgodnie z ówczesnym zwyczajem uzupełniały lekcje prywatne i własna praca. Etiopskiego np. uczyła się sama i to tak skutecznie, że napisała po łacinie gramatykę tego języka. Obok wspomnianych języków i oczywiście hebrajskiego, którego w Niderlandach nauczano dzieci dosyć powszechnie jako języka Biblii, Anna Maria van Schurman władała arabskim (skopiowała nawet w oryginale Koran), włoskim, hiszpańskim, angielskim, prawdopodobnie również chińskim i japońskim. Gdyby wierzyć wszystkim wzmiankom jej współczesnych, to można by wskazać nawet 18 języków, przy czym jej znajomość języka zawsze miała dotyczyć zarówno umiejętności czytania, jak i pisania ${ }^{17}$.

\footnotetext{
${ }^{15}$ Gisbert Voetius, Exercitia et bibliotheca studiosi Theologiae (Utrecht: Apud Wilhelmum Strick, 1644).

${ }^{16}$ Zob. Gisbert Voetius, Politica Ecclesiastica (Amsterdam: Joannes a Waesberge, 1663-1676), Liber I, Tractatus 4.

${ }_{17}$ Zob. np. Schotel, Anna Maria van Schurman, 38.
} 
W 1637 roku zmarła matka Anny Marii van Schurman. Musiała więc ona przejąć obowiązki pani domu, który dzieliła z bratem Johanem Godschalkiem, a z czasem spadła na nią także opieka nad dwiema ciotkami.

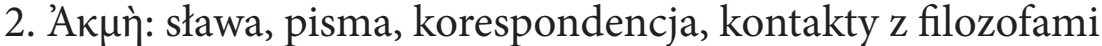

Na początku lat trzydziestych Anna Maria van Schurman zaczęła być znana poza granicami Niderlandów, najpierw we Francji. Pierwszy zaznajomił z nią swoich francuskich korespondentów Claude Saumasie (Claudius Salmasius, 1588-1653), Francuz uczący w Lejdzie, przesyłając autoportret Anny Marii van Schurman. Największy rozgłos zdobyła jednak po opublikowaniu u nieznanego wydawcy, ale za królewską zgodą, w Paryżu w 1638 roku Amica dissertatio inter nobilissimam virginem Annam Mariam a Schurman, et Andraeam Rivetum, De ingenii muliebris ad scientias, et meliores literas capacitate ${ }^{18}$. Książka ta mimo podobieństwa tytułu nie jest tożsama z najbardziej znaną publikacją Anny Marii van Schurman: Dissertatio de ingenii muliebris ad doctrinam et meliores litteras aptitudine. Accedunt quaedam epistolae, eiusdem argumenti, wydaną w Lejdzie w $1641 \mathrm{roku}^{19}$. Amica dissertatio rozpoczyna list Riveta, w którym wychwala on talenty Anny Marii van Schurman, zwłaszcza znajomość języków nie tylko w mowie, ale także w piśmie, oraz zachęca ją do odkrycia swoich umiejętności przed światem. Następnie umieszczony został wyciąg z królewskiego pozwolenia na druk oraz wiersz pochwalny dla Anny Marii van Schurman.

\footnotetext{
${ }^{18}$ Współcześnie egzemplarze tego wydania są bardzo trudno dostępne, opieramy się więc na opisie zawartym w: van Beek, The First Female University Student, 109 i n. Zob. też: Larsen, Anna Maria van Schurman, 108 i n. Dodajmy, że książka ta została przetłumaczona na język francuski i wydana w 1646 roku jako Question Celèbre.

${ }^{19}$ Anna Maria van Schurman, Dissertatio de ingenii muliebris ad doctrinam et meliores litteras aptitudine. Accedunt quaedam epistolae, eiusdem argumenti (Lejda: Ex Officina Elseviriana, 1641). Główna część tej książki została przełożona na język angielski w 1659 roku jako The Learned Maid or Whether a Maid May Be a Scholar? A Logick Exercise; Written in Latine by That Incomparable Virgin Anna Maria à Schurman of Utrecht, With Some Epistles to the Famous Gassendus and Others.
} 
Najistotniejszą część książki stanowią trzy listy z marca 1638 roku: dwa Anny Marii van Schurman do Riveta i jeden Riveta do Anny Marii van Schurman. Tematem korespondencji jest kwestia kształcenia kobiet. Anna Maria van Schurman zwróciła się do Riveta jako swojego mentora w sprawie przyzwolenia na nauczanie kobiet, oczywiście problem ten miał dla niej charakter osobisty. Rivet uważał, że wykształcona kobieta powinna być wyjątkiem, a w ogóle poza zasięgiem kobiet powinny być takie nauki jak prawo, medycyna i teologia. Zauważmy, że tego zalecenia Anna Maria van Schurman nie posłuchała, nie tylko bowiem studiowała teologię, ale także interesowała się medycyną ${ }^{20}$. Kobietom według Riveta wystarczą umiejętności potrzebne do prowadzenia domu. Bóg przecież musiał mieć powód, aby stworzyć dwie różne płci, a więc obowiązki kobiet muszą być odmienne od obowiązków mężczyzn. Rivet powołuje się na słowa św. Pawła z 1 Listu do Tymoteusza $(2,12)$ : „Nauczać zaś kobiecie nie pozwalam ani też przewodzić nad mężem, lecz [chcę, by] trwała w cichości”21. Przywołuje również pracę hiszpańskiego humanisty Juana Luisa Vivesa (1492-1540) zatytułowaną De institutione feminae Christianae (1523). Anna Maria van Schurman uważała zaś, że wszelka wiedza, umiejętności i sztuka są także dla kobiet. Pytała nawet, na mocy jakiego prawa można ograniczyć nauczanie kobiet jedynie do tego, co łączy się z prowadzeniem domu. Czytamy: „Atqui solent obiicere colum et acum tractare, muliebribus satis amplum Lycaeum esse. [...] Quo enim iure, quaeso, haec nobis in sortem cecidere? Divino an humano?”22. Uczenie się jest według niej zajęciem zaszczytnym dla każdego. Kobiety, zwłaszcza o wyższej pozycji społecznej, mają dużo wolnego czasu i wykorzystanie go na kształcenie się byłoby bardzo pożyteczne, ponieważ jak powtarza za Erazmem z Rotterdamu, ,nulla res [...] sic totum puellae pectus occupat ut studium”23. Anna Maria van Schurman broniła równości intelektualnej kobiet i mężczyzn, argumentując, że wszyscy zostali stworzeni przez Boga.

\footnotetext{
${ }^{20}$ Zob. van Beek, The First Femal University Student, 91 i n.

${ }^{21}$ Przekład za: Pismo Święte Starego i Nowego Testamentu. Biblia Tysiąclecia. Wydanie III, tłum. zbiorowe (Poznań-Warszawa: Wydawnictwo Pallattinum, 1982).

22 „Lecz mają zwyczaj wytykać, że dla kobiet wystarczającą szkołą jest brać do ręki kądziel i igłę. [...] Jakim bowiem prawem, pytam, te rzeczy nam przypadły w udziale? Boskim czy ludzkim?"; van Schurman, Dissertatio, 48.

${ }^{23}$ „Żadna rzecz tak nie zajmuje całego serca dziewczyny jak studiowanie”; tamże, 50.
} 
Powoływała się także na książkę francuskiej pisarki Marie le Jars de Gournay (1565-1645) zatytułowaną Légalité des hommes et des femmes (1622).

Omówione listy zostały również włączone, wraz z inną korespondencją, do wspomnianej Dissertatio de ingenii muliebris ad doctrinam et meliores litteras aptitudine ${ }^{24}$, która zawiera najbardziej znany traktat Anny Marii van Schurman, czyli Problema practicum. Num foeminae christianae conveniat studium litterarum?25, poprzedzony wstępem lekarza z Dordrechtu - Johana van Beverwijcka (Johannes Beverovicius; 1594-1647). W wydaniu znajdują się także wiersze pochwalne dla Anny Marii van Schurman. Obok korespondencji z Rivetem (obejmującej nie tylko wspomniane listy z 1638 roku) znajdziemy korespondencję Anny Marii van Schurman z Adolfem van Voorstem (Adolphus Vorstius; 1597-1663) - lekarzem i botanikiem, oraz z dwoma teologami: Andreasem Colviusem (1594-1671) i Jacobusem Lydiusem (1610-1679). List wymienione z Voorstem i Colviusem podejmują temat kształcenia kobiet, korespondencja z Lydiusem omawia zaś teologiczny problem udzielania chrztu osobom zmarłym, w oparciu o rozdział 151 Listu do Koryntian.

Zatrzymajmy się teraz na owym "problemie praktycznym”: Num foeminae christianae conveniat studium litterarum? („Czy chrześcijańskiej kobiecie przystoi zamiłowanie do studiowania nauk?”). Odpowiedź Anny Marii van Schurman ma formę sylogizmów, których konkluzje najpierw argumentują za tym, że przystoi, a następnie zbijają tezę przeciwną. Nawiązując zgodnie z zasadą sola Scriptura do koniecznego w protestantyzmie czytania i studiowania Pisma św., wskazuje na wymóg nauczania również kobiet. Ponieważ celem wszelkich studiów jest zbawienie duszy i głoszenie chwały Boga, Anna Maria van Schurman rozważa, czy każda nauka jest dla tego celu tak samo istotna i czy każda jest odpowiednia dla kobiet. Najważniejsze według niej są: gramatyka, logika i retoryka, a następnie fizyka, metafizyka, historia i nauka języków, szczególnie greki i hebrajskiego. Matematykę, muzykę, poezję i malarstwo uważa za miłe rozrywki, ale bezpośrednio niewnoszące niczego do możliwości osiągnięcia celu zamierzonego, a więc rozwoju cnót moralnych i poszerzania wiedzy teologicznej. Niektóre dziedziny zaś, jak prawo,

\footnotetext{
${ }^{24}$ Listy te znajdziemy również w: van Schurman, Opuscula, 63-95.

${ }^{25}$ Przekład na język polski: Anna Maria van Schurman, „Problem praktyczny: Czy chrześcijańskiej kobiecie przystoi zamiłowanie do studiowania nauk?”, przeł. i oprac. Joanna Usakiewicz, Studia $z$ Historii Filozofii 1(10) (2019): 17-38.
} 
wojskowość czy umiejętność publicznego przemawiania, są według niej w praktyce nie dla kobiet, co wynika z uwarunkowań społecznych, ale jednocześnie uważa, że nie należy pozbawiać kobiet możliwości ich studiowania teoretycznego. Kobiety powinny się kształcić przede wszystkim dlatego, że są bytami ludzkimi, mającymi inteligencję, przyrodzone pragnienie uczenia się oraz możliwość rozumienia nauki i sztuki, czyli tak jak mężczyźni są dziełem Boga. Wszyscy ludzie jako stworzenia Boże mają dążyć do Boga, a to odbywa się na drodze Jego poznania poprzez czytanie i studiowanie Biblii oraz rozwój cnót moralnych, do czego potrzebna jest odpowiednia wiedza. Wykształcenie według Anny Marii van Schurman broni też człowieka przed herezjami. Aby więc być dobrą chrześcijanką, kobieta potrzebuje wykształcenia. Zaznaczyć należy jednak, że Anna Maria van Schurman nie upomina się wyraźnie o dostęp dla kobiet do instytucjonalnego kształcenia. Edukacja dziewcząt to obowiązek rodziców. Dorosła kobieta zaś może dalej się kształcić pod warunkiem, że jest niezamężna. W traktacie Anna Maria van Schurman powołuje się na autorytety filozofów. Znajdziemy odwołania do: Platona (Prawa), Arystotelesa (Metafizyka, Etyka Nikomachejska) oraz oczywiście Seneki (O dobrodziejstwach). Platona i niektóre fragmenty Arystotelesa cytuje po grecku.

Wracając do kolei życia Anny Marii van Schurman, należy wskazać, że Rivet jako tutor księcia Williama na dworze w Hadze w 1632 roku przekazał informacje o Annie Marii van Schurman księżniczce Elżbiecie Palatyńskiej (1618-1680). Najprawdopodobniej udostępnił jej również francuski poemat Anny Marii van Schurman powstały na okoliczność śmierci jej ojca - autorka opisuje w nim m.in. sen o spotkaniu z Panią Filozofią, wskazującą rozum jako przewodnika. Po kilku latach, od roku 1639 uczone kobiety nawiązały korespondencję $e^{26}$. Najpierw księżniczka Elżbieta zwróciła się po radę, co powinna czytać, na co Anna Maria van Schurman odpowiedziała, iż przede wszystkim dzieła historyczne, wskazując, jak wiele można nauczyć się z przeszłych

${ }^{26}$ Listy Anny Marii van Schurman do księżniczki Elżbiety zob. van Schurman, Opuscula, 281-7; 300-303. O relacji tych kobiet zob. np.: Jacqueline Broad, Women Philosophers of the Seventeenth Century (Cambridge: Cambridge University Press, 2002), 17 i n. Księżniczka Elżbieta była jedną z kilku uczonych kobiet, z którymi korespondowała Anna Maria van Schurman. Na uwagę zasługuje np. jej korespondencja w języku greckim z Angielką Bathsuą Makin (ok. 1600-ok. 1675), również autorką traktatu o kształceniu kobiet; zob. Frances Teague, Bathsua Makin, Women of Learning (London: Associated University Presses, 1998). 
wydarzeń. W kolejnym liście z roku 1644 Anna Maria van Schurman pisała o swoim stosunku do scholastyki: „Il est vray, que je fay grand estime des Docteurs Scholastiques, et que sans doute ils me pourroyent fournir de belles occasions pour exercer mon esprit, si je n'en estois divertie le plus souvent par des exercices plus necessaires”27. I dalej: „De sorte, qu’à mon jugement, ils ont fort bien conjoint ensemble ces deux qualitez rarement sociables la subtilité et la realité" 28 . Przyznała wszak, że czasami ich spekulacje są jałowe, a nawet niebezpieczne, co może powodować krytykę de plusieurs gens doctes de notre temps ${ }^{29}$. Wydaje się, że chodzi tu przede wszystkim o Descartes’a, z którym Anna Maria van Schurman spotkała się w 1635 roku, a księżniczka Elżbieta od 1643 roku nawiązała korespondencję $e^{30}$. Warto w tym miejscu zauważyć, że Anna Maria van Schurman, zresztą jak wielu jej krajan, znała myśl Kartezjańską raczej powierzchownie: powszechność rozumu, dualizm substancjalny oraz metoda. Także jej przywiązanie do tradycji i autorytetów scholastycznych nie sprzyjało przyjaznemu spojrzeniu na filozofię Descartes’a. Choć może największy wpływ miał tu Voetius, krytyk Descartes’a.

Zanim nawiązała się korespondencja między Anną Marią van Schurman a księżniczką Elżbietą, jak już wspomnieliśmy, w 1635 roku Anna Maria van Schurman odwiedziła z własnej inicjatywy Descartes’a przybyłego do Utrechtu z wizytą do profesora filozofii Hendrika Reneriego (Henricus Renerius, 1593-1639). Słyszała o nim z pewnością również od Riveta, który spotkał się z filozofem w 1629 roku i który bardzo go podziwiał, ale przede wszystkim jako matematyka. Zauważmy, że Rivet nie opowiedział się po żadnej stronie podczas sporu Descartes’a i Voetiusa ${ }^{31}$. O wspomnianym spotkaniu Anna Maria van Schurman wspomniała w liście do Riveta właśnie z 18 marca tegoż roku. W liście tym przywołała opinię, że Descartes jest czło-

\footnotetext{
${ }^{27}$ „To prawda, że mam wielkie poważanie dla doktorów scholastycznych, i bez wątpienia mogliby mi oni dać świetne sposobności do ćwiczenia mego ducha, gdybym tak często nie była odrywana od tych ćwiczeń przez obowiązki”; van Schurman, Opuscula, 301.

${ }^{28}$ „Zatem moim zdaniem są oni bardzo dobrym połączeniem dwóch jakości rzadko występujących razem: subtelności i poczucia realności”; tamże.

${ }_{29}$ „Wielu uczonych ludzi naszych czasów”; tamże.

${ }^{30}$ Zob. René Descartes, Listy do księżniczki Elżbiety, przeł. Jerzy Kopania (Warszawa: Wydawnictwo Naukowe PWN, 1995).

${ }^{31} \mathrm{Na}$ temat sporu zob. René Descartes, List do Voetiusa, przeł. Joanna Usakiewicz (Warszawa: Wydawnictwo Naukowe PWN, 1998).
} 
wiekiem o wielkiej i raczej niespotykanej wiedzy oraz że jego zdaniem nie mamy do czynienia z postępem wiedzy ludzkiej i dlatego należy pójść pewniejszą nową drogą do prawdy ${ }^{32}$. Co należy podkreślić, nie nawiązała z Descartes'em korespondencji.

W 1638 roku Anną Marią van Schurman zaczął się interesować zaprzyjaźniony z Descartes’em Marin Mersenne. Najpierw pytał o nią w liście z 23 maja tegoż roku Riveta, w czerwcu (dokładnie 27) 1639 roku otrzymał zaś od Johana van Beverwijcka kopię trzeciej części jego zbioru De vitae termino ${ }^{33}$, zawierającej list-esej Anny Marii van Schurman wraz z listem Beverwijcka podkreślającym jej znajomość języków, filozofii i teologii, a nawet, jak zauważa, filozofii scholastycznej ${ }^{34}$. Zbiór ten zawierał głosy w dyskusji zapoczątkowanej w 1632 roku przez van Beverwijcka, dotyczącej wartości i użyteczności medycyny w odniesieniu do problemu, czy człowiek powinien starać się przedłużać swoje życie poprzez korzystanie z umiejętności lekarzy, czy też fatalistycznie przyznać, iż długość życia została wyznaczona przez Boga, a człowiek i tak nie ma na to żadnego wpływu. Odpowiedzi zaproszonych do dyskusji uczonych publikowano w kolejnych tomach od 1634 roku. W przedsięwzięciu wzięło udział 24 uczonych, w tym 12 teologów różnych wyznań, z Niderlandów, Francji i Niemiec, a wśród nich tylko jedna kobieta Anna Maria van Schurman. Wielu uczonych opowiedziało się za tym, że granica między życiem a śmiercią jest niezmienna (terminus fatalis) z perspektywy Boga, a zmienna (terminus mobilis) z perspektywy człowieka. Anna Maria van Schurman, popierając swoją argumentację autorytetem Platona, Cicerona, Seneki, św. Augustyna, św. Tomasza z Akwinu i oczywiście Biblii, twierdziła, że czas życia jest ustalony przez Boga, ale nie należy rozumieć tego fatalistycznie. Bóg, mając szczegółowy plan wobec ludzi, uwzględnił w nim również medycynę. Lekarze zostali niejako zwerbowani do wypełniania planu Bożego na lepszym poziomie, a każdy człowiek ma obowiązek zachowywania swojego zdrowia i życia aż do końca wyznaczonego przez Boga. Głos Anny

\footnotetext{
32 Zob. Larsen, Anna Maria van Schurman, 278-279.

${ }^{33}$ Johannes Beverovicius, De vitae termino, fatali, an mobili? Cum doctorum responsis. Pars tertia, et ultima, nunc primum edita. Seorsim accedit nobilissimae et doctissimae virginis Annae Mariae à Schurman de eodem argumento Epistola, totius disputationis terminus (Lejda: Johannis Maire, 1639).

${ }^{34}$ Zob. Larsen, Anna Maria van Schurman, 50.
} 
Marii van Schurman spotkał się z szerokim odzewem, został przetłumaczony na niderlandzki, niemiecki oraz francuski i wielokrotnie był publikowany oddzielnie lub w innych pracach.

11 listopada 1640 roku w liście do Mersenne’a Descartes napisał: „Ów Voetius wypaczył także pannę Schurman; miała ona bowiem wyjątkowy talent do poezji, malarstwa i podobnych wdzięcznych zajęć, tymczasem już od pięciu czy sześciu lat owładnął nią tak całkowicie, iż nie zajmuje się niczym innym jak tylko kontrowersjami teologicznymi, co sprawia, że wszyscy dobrze wychowani ludzie po prostu unikają rozmowy z nią" ${ }^{35}$. W kontekście późniejszego przystąpienia Anny Marii van Schurman do labadystów, według Adriena Bailleta (1649-1706), biografa Descartes’a, filozof: „sans être prophéte avoit eû quelque préssentiment de ce qui devoit arriver à cette pauvre fille. Il jugeoit que la curiosité demesurée de trop sçavoir, et de pénétrer dans les mystéres les plus inaccessibles de la Théologie pour les personnes de son séxe, pourroit bien l'entraîner trop loin, et dégénérer en une présomption qui luy attireroit le sort des vierges folles et imprudentes de l'Evangelie"36. Dodajmy, że także Rivet w liście do Huygensa (26 sierpnia 1639 roku) krytycznie pisał o wpływie Voetiusa na Annę Marię van Schurman, a mianowicie twierdził, iż zbyt obciąża ją pracą i niszczy tego ducha tak spragnionego wiedzy. Ostateczne zerwanie kontaktów Anny Marii van Schurman i Descartes’a nastąpiło po ich kolejnym spotkaniu. Tym razem to filozof odwiedził Annę Marię van Schurman latem 1649 roku, gdy udawał się do Szwecji. Descartes, zobaczywszy na jej biurku hebrajską Biblię, miał powiedzieć, że marnuje ona cenny czas na tak mało znaczącą rzecz jak studiowanie hebrajskiego ${ }^{37}$. A kiedy Anna Maria van Schurman wyjaśniła, jak ważne jest czytanie Pisma św. w oryginale, Descartes miał odpowiedzieć, że kiedyś też tak uważał, ale

\footnotetext{
${ }^{35}$ Cyt. za: Descartes, Listy do Regiusa, 107-108.

${ }^{36}$ „Nie będąc prorokiem, miał przeczucie tego, co stanie się z tą biedna dziewczyną. Sądził, że nadmierna ciekawość, aby wiedzieć zbyt wiele i przenikać tajemnice teologii bardziej niedostępne osobom jej płci, będzie mogła doprowadzić ją za daleko i przerodzić się w zarozumiałość, która ściągnie na nią los panien płochych i nierozsądnych z Ewangelii [zob. Mt 25, 1-13]"; Adrien Baillet, La vie de Monsieur Descartes. Seconde Partie (Paris: Chez Daniel Horthemels, 1691), 61 (Livre V, Chapitre VIII). Baillet kreśli również sylwetkę Anny Marii van Schurman jako osoby bardzo utalentowanej i wykształconej; zob. tamże, 60-62.

${ }^{37}$ Naukę hebrajskiego za marnowanie czasu miała uznać Marie le Jars de Gournay w jednym z listów do Anny Marii van Schurman. Jej odpowiedź zob. van Schurman, Opuscula, 318-320.
} 
nie znalazł w opisie stworzenia z Księgi Rodzaju niczego jasnego i wyraźnego. Od tego spotkania Anna Maria van Schurman nie chciała mieć już z nim nic wspólnego ${ }^{38}$. Z pewnością cieniem na ich znajomości położył się wpływ, jaki Voetius wywarł na kształtowanie się oceny filozofów i ich poglądów u Anny Marii van Schurman, oraz ostra krytyka kartezjanizmu. Może inaczej potoczyłyby się sprawy, gdyby bez uprzedzeń odczytali konstatację Descartes’a: „le bon sens est la chose du monde la mieux partagée” ${ }^{39}$, którą można przecież interpretować jako twierdzenie o równości rozsąaku u obu płci, na czym przecież opierała się Anna Maria van Schurman, nawołując do kształcenia kobiet.

Warto też wspomnieć jeszcze o innym filozofie, który pojawił się w życiu Anny Marii van Schurman, a do którego miała całkiem odmienny stosunek niż do Descartesa. Mowa o francuskim filozofie Pierze Gassendim (1592-1655). Podobnie jak Anna Maria van Schurman interesował się językami klasycznymi i orientalnymi, krytykował Descartes'a (Gassendi jest autorem Zarzutów piątych do Medytacji o pierwszej filozofii oraz Disquisitio metaphysica seu dubitationes et instantiae adversus Renati Cartesii Metaphysicam et responsa; Amsterdam 1644) ${ }^{40}$, wracał do filozofii klasycznej (De vita et moribus Epicuri libri octo, Lyon 1647; Syntagma philosophiae Epicuri, cum refutationibus dogmatum quae contra fidem christianam ab eo asserta sunt, Lejda 1658). Wymienili w roku 1644 dwa niezbyt obszerne listy na temat Dissertatio Anny Marii van Schurman ${ }^{41}$. Stanowią one dobry przykład kurtuazyj-

\footnotetext{
${ }^{38}$ Opis spotkania zob. Gottfried Arnold, Fortsetzung und Erläuterung Dritter und der Vierdter Theil der unparthenischen Kirchen und Ketzer Historie (Frankfurt am Mann: Thomas Fritschens, 1729), 1341-1342 (Supplementa).

${ }^{39}$ René Descartes, Discours de la mèthode (Paris: Éditions Sociales, 1950), 39.

${ }^{40}$ Uczeni stawiają tezę, że Anna Maria van Schurman czytała to dzieło; zob. Larsen, Anna Maria van Schurman, 96.

${ }^{41}$ Oba listy odnajdziemy w: Pierre Gassendi, Opera omnia in sex tomos divisa (Lejda: Sumptibus Laurentii Anisson et Joannis Baptistae Devenet, 1658). List Anny Marii van Schurman znalazł się w: taż, Opuscula, 212-214). Oba listy datowane są na rok 1644, list Anny Marii van Schurman na kalendy styczniowe (napisany w Utrechcie), a list Gassendiego na idy czerwcowe, czyli 13 (napisany w Paryżu). Gdy jednak wczytamy się w ich treść, okazuje się, że to list Anny Marii van Schurman jest odpowiedzią na list Gassendiego. Na początku Anna Maria van Schurman odwołuje się do tego, że w swoim piśmie Gassendi uznał ją za przykład cnoty, i rzeczywiście w liście Gassendiego to odnajdujemy. Pisze też, że to lektura Dissertatio, którą tak życzliwie Gassendi przyjął, musi być w większości przyczyną dobrego o niej zdania.
} 
nej wymiany listów w siedemnastowiecznej Republica Litteraria. Gassendi rozpoczął list od nawiązania do swojej lektury Dissertatio, której egzemplarz otrzymał od Duchesniusa (André Duchesne, 1584-1640), francuskiego geografa i historyka. Już w pierwszym zdaniu nazwał Annę Marię van Schurman decus („ozdobą") i to rarum („rzadką") oraz incomparabile („wyjątkową"). Wyraźnie wskazał, że dla niego kobieta wykształcona to rzadkość i wyjątek wśród płci pięknej. To zdanie podkreślają słowa następne, w których pisał, iż zadziwiło go (stupor occupat - „zdumienie ogarnia”), że czytając pracę, znalazł potwierdzenie tak pochlebnych opinii o intelekcie i umiejętnościach Anny Marii van Schurman, o czym wcześniej tylko słyszał. Dalej przyznał, że kobiety mogą wykwintnością swojej wymowy budzić podziw, ale według niego zwykle jest to tylko na pokaz i powierzchowne, nie jest spontaniczne i nie opiera się na przyrodzonych zdolnościach. Inaczej jest u Anny Marii van Schurman. Podkreślał jej umiarkowanie, prawość i prostotę. Malował jej portret jako osoby, dla której pochwały stanowią sposobność do chwalenia Boga i doskonalenia się. Mówiąc o mądrości Anny Marii van Schurman, nazywał ją szczęśliwą (felix). Jest to wyraźne nawiązanie do filozoficznego rozumienia szczęścia jako osiągnięcia cnoty i mądrości. Zakończył swój list wyznaniem, że musiał dać to świadectwo podziwu dla autorki przeczytanej rozprawy, aby nie posądzono go o zazdrość, oraz iście kaznodziejską zachętę, aby podążała ona dalej tą samą drogą. Jeśli odniesiemy się do tematu poruszanego w Dissertatio, czyli możliwości kształcenia kobiet w tym, co Gassendi nazywa bonae litterae, a Anna Maria van Schurman bonae artes sive litterae, to Gassendi z pewnością nie byłby tak przychylny temu pismu, gdyby nie wspomniana bardzo umiarkowana postawa Anny Marii van Schurman i jej odniesienia do chrześcijaństwa. Gassendi, pisząc bowiem o autorce, wyraźnie podkreślał, że jest ona ewenementem wśród swojej płci, jej sposób

Gassendi zaś rozpoczyna swój list od zaznaczenia, że przeczytał Dissertatio Anny Marii van Schurman i odnalazł w niej dowody na to wszystko, co dobrego o intelekcie i charakterze autorki do tej pory słyszał. Wydawca Anny Marii van Schurman nie mógł na to zwrócić uwagi, bo zamieszcza tylko jej list. Wydawcy Gassendiego, choć zebrali korespondencję w jednym tomie jego Opera omnia, tomie 6, mogli tego nie zauważyć, ponieważ nie opublikowali listów obok siebie: list Anny Marii van Schurman na stronach 484-485, a Gassendiego na stronach 198-199. Być może to sama Anna Maria van Schurman pomyliła rok: pisze wszak 1 stycznia, a wiemy, jak często zdarza się, że na początku roku mylimy się w dacie. 
wyrażania odbiega od wrodzonej kobietom powierzchowności czy płytkości (levitas ingenita), a jej postawa odznacza się wielkim umiarkowaniem i pokorą.

Anna Maria van Schurman rozpoczęła swój list od nawiązania do tego, iż Gassendi nazwał ją przykładem cnoty; uznała to za najlepszą charakterystykę swej osoby. Jednak zaznaczyła od razu, iż wszystkie pochwały, jakie skierował pod jej adresem, nie tyle są zasłużone, ile odzwierciedlają prawego ducha Gassendiego i wręcz zgrzeszyłaby (peccare), gdyby nie wskazała, jak wspaniałym jest on człowiekiem. Za dowód miłości Gassendiego do prawdziwej mądrości (veram sapientiam amoris argumentum) uznała fakt, iż nie pogardził iskierką (scintillula) mądrości kobiecej, a nawet ją roznieca. Gassendi to dla Anny Marii van Schurman także człowiek wyróżniający się ze względu na swoją cnotę i uczynki oraz myśliciel zasłużony dla percepcji starożytnej filozofii.

W 1648 roku zostają opublikowane w Lejdzie Opuscula Hebraea, Graeca, Latina, Gallica. Prosaica et metrica. Wydawcą tego tomu zawierającego m.in. Problema practicum, korespondencję oraz wiersze pochwalne dla Anny Marii van Schurman był kalwiński teolog Friedrich Spanheim (1600-1649). Książka stała się bardzo popularna, choć prawdopodobnie ze względu na wyznanie autorki została w 1658 roku zakazana przez Kościół katolicki.

\section{Ostatni znamienny wybór życiowy}

W latach czterdziestych i pięćdziesiątych rozgłos Anny Marii van Schurman był na tyle duży, że ona sama zaczęła wycofywać się z tak intensywnego życia: ograniczyła odpisywanie na listy i przyjmowanie odwiedzających ją gości. Zaczęła również zastanawiać się nad samą istotą swojej sławy, nad tym, że ludzie traktują ją jak jakąś ciekawostkę i rzadkość. Skupiła się na życiu rodzinnym, zajmowała się dwiema starymi ciotkami. W latach 1653-1654 odbywała wraz z nimi i bratem podróż do Kolonii, gdzie mieli nadzieję odzyskać rodzinne dobra, co się nie udało.

W 1661 roku brat (Johan), będąc w Bazylei, dowiedział się o Jeanie de Labadiem i udał się do Genewy na spotkanie z nim, o czym entuzja- 
stycznie doniósł siostrze w 1662 roku. Jean de Labadie (1610-1674) ${ }^{42}$ to francuski duchowny, wychowanek jezuitów, który opuściwszy łono Kościoła katolickiego, wstąpił do Kościoła reformowanego, aby ostatecznie uznać się za proroka wezwanego przez Ducha św. i głosić ideę Kościoła apostolskiego. Od 1665 roku był pastorem w Middelburgu, dokąd regularnie jeździła Anna Maria van Schurman, a de Labadie podczas pobytu w 1666 roku w Utrechcie zatrzymał się w jej domu (jej brat już nie żył, zmarł w 1664 roku). W 1669 roku de Labadie założył własną wspólnotę „świętych” przygotowujących się na ponowne przyjście Chrystusa, opartą na surowej ascezie oraz odrzuceniu własności. Doktryna labadyzmu głosiła konieczność odcięcia się od marności „świata” oraz podwójną predestynację. Labadyści przyjmowali Pismo św. za jedyną podstawę wiary i wszelkich praw. Istniejące Kościoły uznawali za skażone i nienadające się już do naprawy. Kościół według nich nie ma świętości niezależnej od świętości swoich członków. Istnieje Kościół widzialny prawdziwych wiernych, którzy dzięki predestynacji zostali włączeni w Boże odkupienie - to właśnie wspólnota labadystów. Prawdziwi wierni oddają cześć Bogu każdym swoim czynem w każdej chwili, kult bowiem nie jest związany z miejscem, czasem czy rzeczami zewnętrznymi.

Anna Maria van Schurman, która dostrzegała rozdźwięk między obecnym bogactwem Niderlandów a prostotą życia przodków, próbowała aktywnie działać na rzecz reform w Kościele, w którym jednak dochodziło do coraz liczniejszych sporów dotyczących m.in.: egzegezy Pisma św., relacji wiary i rozumu czy sekularyzacji Kościoła. Ostatecznie uznała jednak, że to de Labadie przedstawia i proponuje jedyną słuszną drogę. Sprzedała dom oraz większość ruchomości i przystąpiła do wspólnoty. Po zerwaniu de Labadiego z Kościołem reformowanym wspólnota udała się do Herford (Niemcy), gdzie od 1667 roku w luterańskim zakonie żyła księżniczka Elżbieta Palatyńska. Przebywali tam dwa lata, po czym w 1672 roku przenieśli się do duńskiej Altony. Tu Anna Maria van Schurman wydała pracę

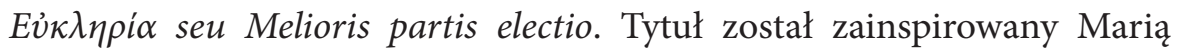
z Ewangelii Łukaszowej - kobieta, przysłuchując się Jezusowi, wybrała to,

${ }^{42}$ Więcej na jego temat zob. Leszek Kołakowski, Świadomość religijna i więź kościelna, (Warszawa: Wydawnictwo Naukowe PWN, 2009), 500 i n. 
co lepsze ( $Ł k$ 10,42b). Można też dostrzec w tej autobiograficznej rozprawie inspiracje Wyznaniami św. Augustyna. Po śmierci założyciela w 1674 roku wspólnotą labadystów kierował Piotr Yvon (1646-1707), który przeniósł ją do niderlandzkiego Wieuwerd. Gdy Anna Maria van Schurman miała około 50 lat, zaczęła powoli tracić wzrok, a w ostatnim roku życia dokuczała jej podagra i reumatyzm. Zmarła 4 maja 1678 roku.

Zakończmy ten krótki opis życia i twórczości siedemnastowiecznej uczonej słowami pochodzącymi z osiemnastowiecznego rękopisu z Archiwum Radziwiłłowskiego: „Anna Maria Schurmann, wiele języków umiejąca, doskonale oprócz tego w filozofii, poetyce, w retoryce etc. udoskonalona była; wymalowawszy sama swój portret podpisała: Cernitis hic picta nostros immagine vultus,/Si negat ars formam, gratia vestra dabit (»widzicie tu na portrecie wymalowaną moją twarz; jeśli sztuka nie mówi nic o mej piękności, użyczy mi jej wasza łaskawość«)”33.

\section{Bibliografia}

Academiae Ultraiectinae Inanguratio una cum Orationibus inanguralibus. 1636. Utrecht: Ex Officina Aegidii et Petri Roman.

Arnold Gottfried. 1729. Fortsetzung und Erläuterung Dritter und der Vierdter Theil der unparthenischen Kirchen und Ketzer Historie. Frankfurt am Mann: Thomas Fritschens.

Baillet Adrien. 1691. La vie de Monsieur Descartes. Seconde Partie. Paris: Chez Daniel Horthemels.

Beverovicius Johannes. 1639. De vitae termino, fatali, an mobili? Cum doctorum responsis. Pars tertia, et ultima, nunc primum edita. Seorsim accedit nobilissimae et doctissimae virginis Annae Mariae à Schurman de eodem argumento Epistola, totius disputationis terminus. Lejda: Johannis Maire.

Broad Jacqueline. 2002. Women Philosophers of the Seventeenth Century. Cambridge: Cambridge University Press.

${ }^{43}$ Cyt. za: Dawna facecja polska (XVI-XVIII w.), oprac. Julian Krzyżanowski i Kazimiera Żukowska-Billip (Warszawa: PIW, 1960), 481-482. Istnieje kilka autoportretów i portretów Anny Marii van Schurman z takim podpisem; zob.: van Schurman, Opuscula; van Beek, The First Female University Student, 37, 138, 162, 165. 
Dawna facecja polska (XVI-XVIII w.). Oprac. Julian Krzyżanowski i Kazimiera Żukowska-Billip. Warszawa: PIW, 1960.

Descartes René. 1950. Discours de la mèthode. Paris: Éditions Sociales.

Descartes René. 1995. Listy do księżniczki Elżbiety, przeł. Jerzy Kopania. Warszawa: Wydawnictwo Naukowe PWN.

Descartes René. 1996. Listy do Regiusa. Uwagi o pewnym pisemku, przeł. Jerzy Kopania. Warszawa: Wydawnictwo Naukowe PWN.

Descartes René. 1998. List do Voetiusa, przeł. Joanna Usakiewicz. Warszawa: Wydawnictwo Naukowe PWN.

Gassendi Pierre. 1658. Opera omnia in sex tomos divisa. Lejda: Sumptibus Laurentii Anisson et Joannis Baptistae Devenet.

Hermann Brigitte. 2003. La demoiselle savante ou Histoire d'Anne Marie de Schurman, 1607-1678. Paris: Bartillat.

Kołakowski Leszek. 2009. Świadomość religijna i więź kościelna. Warszawa: Wydawnictwo Naukowe PWN.

Larsen Anne R. 2016. Anna Maria van Schurman, "The Star of Utrecht". The Educational Vision and Reception of a Savante. Oxon-New York: Routledge.

Pismo Święte Starego i Nowego Testamentu. Biblia Tysiąclecia. Wydanie III, przeł. zbiorowe. Poznań-Warszawa: Wydawnictwo Pallattinum, 1982.

Schotel G. D. J. 1853. Anna Maria van Schurman. 's-Hertogenboch: Gebroeders Muller.

Targosz Karolina. 1985. Jana Sobieskiego nauki i peregrynacje. Wrocław-Warszawa-Kraków-Gdańsk-Łódź: Zakład Narodowy Imienia Ossolińskich Wydawnictwo Polskiej Akademii Nauk.

Teague Frances. 1998. Bathsua Makin, Women of Learning. London: Associated University Presses.

Van Beek Pieta. 2004. The First Female University Student: Anna Maria van Schurman (1636). Utrecht: Igitur, Utrecht Publishing and Archiving Services.

Van Beverwijck Johan. 1643. Van de Wtnementheyt des Vorovwelicken Geslachts. Dordrecht: Hendrick van Esch.

Van Schurman Anna Maria. 1641. Dissertatio de ingenii muliebris ad doctrinam et meliores litteras aptitudine. Accedunt quaedam epistoale, eiusdem argumenti. Lejda: Ex Officina Elseviriana.

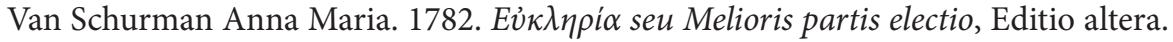
Dessaviae: Sumptibus Societatis Typographicae.

Van Schurman Anna Maria. 1648. Opuscula Hebraea, Graeca, Latina, Gallica. Prosaica et metrica. Lejda: Ex Officina Elseviriorum.

Van Schurman Anna Maria. 2019. „Problem praktyczny: Czy chrześcijańskiej kobiecie przystoi zamiłowanie do studiowania nauk?", przeł. i oprac. Joanna Usakiewicz. Studia $z$ Historii Filozofii 1(10): 17-38. 
Voetius Gisbert. 1644. Exercitia et bibliotheca studiosi Theologiae. Utrecht: Apud Wilhelmum Strick.

Voetius Gisbert. 1663-1676. Politica Ecclesiastica. Amsterdam: Joannes a Waesberge.

\section{Abstract \\ Anna Maria van Schurman (1607-1678) - the Ocellus of the Netherlands}

Anna Maria van Schurman was a seventeenth-century scholar, poet, and painter. Becoming proficient in many languages, she was greatly admired by her contemporaries. She wrote poetry, prose works, and produced paintings and engravings. Her best known text Dissertatio de ingenii muliebris ad doctrinam et meliores litteras aptitudine (1641) is dedicated to women's rights to education. She also

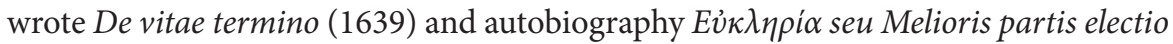
(1673). In the Eukleria she not only depicted her life, but also explained the reasons for joining the Labadists. Anna Maria van Schurman kept up correspondence with many people, for example, André Rivet (1572-1651), Marin Mersenne (1588-1648), Pierre Gassendi (1592-1655), Jean-Louis Guez de Balzac (1597-1654). The Calvinist theologian and the opponent of philosophy of René Descartes, Gisbertus Voetius (1589-1679) was a very important person in her life. Thanks to him Anna Maria van Schurman could study at the University of Utrecht. This article presents the biography and works of Anna Maria van Schurman. Its author pays special attention to her connections with philosophy, with which she began to get acquainted at the age of 11 by reading Seneca's writings. The basis for these considerations is source materials about Anna Maria van Schurman's life, her works and selected letters.

Key words: Anna Maria van Schurman; Descartes, Gassendi; women’s education.

\section{Streszczenie}

\section{Anna Maria van Schurman (1607-1678) - Ocellus Niderlandów}

Anna Maria van Schurman to niezwykle ceniona przez sobie współczesnych siedemnastowieczna uczona, poetka, malarka władająca kilkunastoma językami. Pozostawiła po sobie utwory poetyckie, pisma prozą, obrazy i ryciny. Najbardziej znany jej tekst to poświęcona problemowi edukacji kobiet Dissertatio de ingenii 
muliebris ad doctrinam et meliores litteras aptitudine (1641). Napisała również:

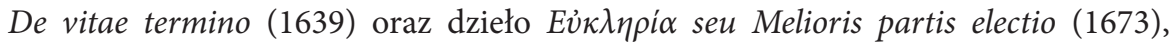
w którym opisała swoje życie oraz przedstawiła obronę swego przystąpienia do labadystów. Anna Maria van Schurman prowadziła także rozległą korespondencję. Adresatami jej listów byli m.in.: André Rivet (1572-1651), Marin Mersenne (1588-1648), Pierre Gassendi (1592-1655), Jean-Louis Guez de Balzac (1597-1654). Bardzo istotną postacią w życiu Anny Marii van Schurman był kalwiński teolog, przeciwnik filozofii René Descartes'a, Gisbert Voetius (1589-1679). Dzięki niemu mogła studiować na Uniwersytecie w Utrechcie. W artykule, przedstawiającym sylwetkę Anny Marii van Schurman, zwrócono szczególną uwagę na jej związki z filozofią, z którą zaczęła zapoznawać się w wieku lat 11 dzięki lekturze pism Seneki. Podstawą rozważań są materiały źródłowe o życiu Anny Marii van Schurman, jej pisma oraz wybrana korespondencja.

Słowa kluczowe: Anna Maria van Schurman; Descartes; Gassendi; kształcenie kobiet. 